\title{
Multiculturalism in Javanese Humor (A Case Study in 'Sing Lucu' Rubric of Panjebar Semangat Magazine)
}

\author{
Valentina Widya Suryaningtyas, \\ Nina Setyaningsih \\ Universitas Dian Nuswantoro (Udinus), Semarang \\ valentina.widya@dsn.dinus.ac.id \\ nina.setyaningsih@dsn.dinus.ac.id
}

Article History: Submitted 20 June 2017; Accepted 16 March 2018; Published 30 March 2018

\begin{abstract}
We play with language when we manipulate it as a source of enjoyment, either for ourselves or for the benefit of others. We take some words, phrases, sentences, and other linguistic features and make them do things that they do not normally do. This language manipulation can result in humor. Humor has formed a substantial part of Javanese culture. Some jokes in Javanese contain local wisdom and this plays an important role to maintain the social and cultural norms. This paper examines the humor used in Sing Lucu rubric which contains jokes in Panjebar Semangat magazine. In Indonesia, there are only a few printed media that specialize in Javanese language and culture. One of them is Panjebar Semangat. It is a magazine that maintains Javanese culture, especially by the use of Javanese language and Javanese related contents. This paper aims to identify the types of humor and to explore the multiculturalism through the Javanese language expression. This study is framed by drawing on theories on humor, language play, and ambiguity. The result shows that there are three types of humor used in Sing Lucu: positive, negative, and neutral. Positive and neutral jokes have entertaining contents, while negatives jokes contain stereotyping of certain races. Some jokes are not based on facts and therefore they do not always represent certain races stereotyped in such jokes.
\end{abstract}

Keywords: humor, Javanese, media, multiculturalism

\begin{abstract}
ABSTRAK
Kita bermain dengan bahasa ketika kita mencoba memanipulasi bahasa sebagai sumber kesenangan, baik untuk diri sendiri maupun untuk orang lain. Kita menggunakan sebagian kata, frase, kalimat, dan aspek kebahasaan lainnya dan kemudian mengubah fungsinya menjadi fungsi yang tidak biasanya. Manipulasi bahasa ini kemudian dapat
\end{abstract}


menjadi sebuah bumor. Humor itu sendiri sudah menjadi bagian dari budaya Jawa. Beberapa humor di Jawa mengandung kearifan lokal dan bumor ini berperan dalam mempertahankan norma sosial dan budaya. Penelitian ini membahas tentang bumor yang ada di rubrik Sing Lucu yang berisi lelucon di majalah Panjebar Semangat. Di Indonesia, ada beberapa majalah yang mengkhususkan isinya pada bahasa dan budaya Jawa, salah satunya adalah Panjebar Semangat. Majalah ini mempertahankan budaya Jawa terutama melalui penggunaan bahasa Jawa dan isi yang terkait dengan budaya Jawa. Penelitian ini bertujuan untuk mengidentifikasi jenis bumor dan untuk menganalisis multikulturalisme melalui ekspresi bahasa Jawa. Penelitian ini menggunakan teori tentang bumor, permainan bahasa, dan ketaksaan. Hasil penelitian ini menunjukkan babwa dalam rubrik Sing Lucu terdapat tiga jenis bumor yaitu: positif, negatif, dan netral. Humor positif dan dan netral mengandung konten menghibur, sementara guyonan negatif berisi stereotipe suku tertentu. Beberapa lelucon tidake berdasarkan fakta, oleb karena itu lelucon tersebut tidak selalu mencerminkan stereotipe suku tertentu.

Kata kunci: humor, Jawa, media, multikulturlisme

\section{INTRODUCTION}

Humans communicate by using language. They deliver a message, idea, or meaning to an interlocutor. Crystal (1998) points out that everyone plays with language or responds to language. We play with language when we manipulate it as a source of enjoyment, either for ourselves or for the benefit of others. We take some words, phrases, sentences, and other linguistic features and make them do things that they do not normally do. This language manipulation can result in humor.

Humor as an element of communication can be created from misinterpretation which occurs in either spoken or written form. Humor can be seen in various genres and text types. All elements of a language, from the smallest level (phones) to the biggest level (discourse) are used to create a humorous effect. This effect, which delivers any form of unexpectedness, misunderstanding, and nonsense, is expected to be able to be perceived well by the hearer/reader.

In addition, Indonesia is a country of different ethnic groups. Schermerhorn (in Lowe, 1986) points out that an ethnic group is "a collectivity within a larger society having real or putative common ancestry, memories of a shared historical past, and a cultural focus on one or more symbolic events defined as the epitome of their peoplehood. Examples of such symbolic events are kinship patterns, physical contiguity (as in localism or sectionalism), religious affiliation, language or dialect forms, tribal affiliation, nationality, phenotypal features, or any combination of these. A 
necessary accompaniment is some consciousness of kind among members of the group." Dealing with humor, then, as it is also related with ethnicity, Davies (in Lowe, 1986) asserts that ethnic jokes "delineate the social, geographic and moral boundaries of a nation or ethnic group." Furthermore, Lowe concludes that humor plays an important role in group identity formation and solidarity.

Humor has formed a substantial part of Javanese culture. There are many TV humor shows, movies, and rubrics in printed media that have big audiences. Even the late former president of Indonesia, Abdurrahman Wahid (Gus Dur) was famous for his jokes. Some jokes in Javanese contain local wisdom and this, according to Bascom (in Wijana, 2003) plays an important role to maintain the social and cultural norm.

This paper examines the humor used in Sing Lucu rubric. This rubric contains humorous texts and jokes in Panjebar Semangat magazine. In Indonesia, there are only a few printed media that specialize in Javanese language and culture. One of these media is Panjebar Semangat. It is a magazine that maintains Javanese culture, as can be seen from the use of Javanese language and Javanese related contents.

This paper aims to identify the types of humor in Sing Lucu column and to explore the multiculturalism through the Javanese language expression. The humorous texts can be analyzed in terms of their sounds and meanings through language play and ambiguity. These texts also show jokes that deal with various ethnic groups in Indonesia. Therefore, they demonstrate the multiculturalism in the country.

\section{Humor}

Humor as a phenomenon, it's philosophical, psychological, and physiological nature, its aesthetic value, its relation to truth, ethical standards, customs, and norms (Raskin, 1979). According to Lefcourt (2001) humor was initially as an undimensional construct associated with positive effects on health and well being. Researcher typically defines humor as a multidimensional construct consisting of both adaptive and maladaptive styles of humor use (Ruch, 1996). Humor can be defined in terms of an aesthetic response, as measured by funnies ratings of cartoon and jokes. When humor is described in this way, studies have typically found that shared and non-shared environmental factors account for the variance in humor appreciation (Cherkas et al., 2000; Nias \& Wilson, 1977; Wilson et al., 1977). Humor is used in literature, in society and it is treated holistically and generally and naturally, no formal analysis of the linguistics aspect has ever been undertaken. 
Verbal humor which is of interest to linguists and is thus addressed here stands vis-a -vis non-verbal humor emerging from, for instance, pictures or body language (Norrick 2004a in Raskin (1979)). Verbal humor is understood as that produced by means of language or text (Raskin 1985; Attardo and Raskin 1991; Chiaro 1992; Attardo 1994; 1 Alexander 1997; Norrick 1986, 2004a). According to Raskin (1979) in verbal humor it is important to look at the script carefully because it represents common sense cognitive stored in the mind of native speaker.

Joke as a prototypical form of verbal humor is produced orally in conversations or published in collections (Dynel, 2009). A joke comprises a build up and punches (Hockett, in Dynel 2009). The set up is normally built of a narrative or/ and a dialogue (Attardo and Chabanne 1992 in Dynel 2009), while the punchline (Attardo 1994, 2001 in Dynel 2009) is the final portion of the text, which engenders surprise and leads to incongruity with the set-up. As Dynel (2009) concludes, there are few categories of jokes such as shaggy-dog stories (lengthy stories without punchlines) (Chiaro 1992), riddles (questions followed by unpredictable and silly answers) (Chiaro 1992; Dienhart 1999) or one-liners (one-line jokes with punchlines reduced to a few words) (Chiaro 1992; Norrick 1993).

In analyzing humor there are units of conversational humor range. The unit of conversational humor range includes single-word lexemes, phrasemes to whole sentences and even multi-turn exchanges interwoven into non humorous discourse (Dynel, 2009). The shortest humorous chunks are lexemes and phrasemes (Mel'c ${ }^{\vee}$ uk 1995, 1998), i.e. lexical units used in discourse for a humorous effect, whose semantic import is usually germane to the whole utterance, often non-humorous as such. The humorous potential of lexemes and phrasemes resides in their novelty, unprecedented juxtapositions (incongruity) of their constituents and the new semantic meaning they carry. Even if borrowed from popular media discourse, they are widely repeated in appropriate conversational contexts, they are unlikely to be officially conventionalized and listed in dictionaries as lexical items, and thus always retaining the quality of exceptionality. The two humorous categories, lexemes and phrasemes, deserve meticulous attention, as they do not appear to have been widely discussed in humor literature (Chiaro 1992; Alexander 1997).

According to Dynel (2009) most humorous lexemes can be conceptualized as neologisms. Those are new words indispensable for naming new inventions and discoveries. However, speakers will also incorporate new words in their idiolects, the sole reason being the novelty of expression and humor. Humorous neologisms capitalize on various word-formation processes. 


\section{Language Play}

Language play, according to Crystal (1998), is when people play with their own language or respond to the play of the language. Some of them will be entertained by this language play. For example, as stated in the previous research conducted by Wijana (2003). He finds that people in Jogjakarta, Indonesia are not only entertained by the language play and turned it into humor but they are also obsessed with it. Language play becomes a pleasure to communicate with others, especially if the response matches our inclination. Language play then leads into humor. The function of humor is to deliver the information, show the feeling of happy, sad, annoy, or maybe sympathy. Furthermore, Hermintoyo (2011) also says that humor can also release the tense inside our body and as a way to criticize because sometimes it can decrease the tense in a confrontation. Sometimes humor is created not only to reach the enjoyment but it also makes people guess the meaning. Hence, it becomes very obvious that humor is quite close with culture and places. As exemplified by Wijana (2003), humor in Dagadu is sometimes difficult to understand for people outside Jogjakarta. By using language play, the copy writers try to create designs which represent the people in Jogjakarta. It is also to show the activities in that city and to deliver the social criticism related with sociocultural problems in Jogjakarta.

Crystal (1998: 1) states that we play with language when we manipulate it as a source of enjoyment, either for ourselves or for the benefit of others. The linguistic features such as a word, a phrase, a sentence, a part of word, a group of sounds, a series of letter can be manipulated to achieve the goal. Crystal (1998:9) also says that the whole point about conversational language play is that it is unregulated and anarchic. With language play, moreover, everyone is equal- in the sense that, once we have achieved adult levels of fluency in a language, we have acquired all the tools and expertise we need in order to play with it successfully.

One aspect of humor is ambiguity in meaning. Ambiguity of meaning can be resulted from homonymy, homography, and polysemy. Verbal humor generally relies on ambiguity, that is, on the use of word, phrase, and sentence, or longer unit which can be understood in two different, usually, conflicting ways. This in turns relates to the tendency, inherent in language, for different phonetic and semantic chains to cross one another. We have all encountered the type of utterance which, in all innocence, is suddenly to carry a second possible meaning which clashes with the first. Raskin states that the usage of ambiguity is happened because there is non-bonafide communication process. 


\section{Humor Styles}

Humor styles deal with how people use humor. Positive humor gives adaptive function. It includes self-enhancing humor, which involves a tendency to be amused by the incongruities of life such as adversity and helps people attain distance from problems in stressful situations. It also includes affiliative humor, which describes a person's tendency to facilitate relationships by telling jokes and engaging in funny banter. On the other hand, negative humor styles are maladaptive, because humor at one's own or another's expense jeopardizes social relationships and self-worth. It covers aggressive humor, which refers to irony, sarcasm, teasing, and mockery as well as to sexist and racist humor, and is associated with manipulating or belittling others. (Scheel and Gockel, 2017)

\section{Indonesian Ethnic Groups}

When talking about multiculturalism, relation between ethnic groups is considered. There are over 300 ethnic groups in Indonesia. Javanese make up $41 \%$ of the total population. This ethnic group is concentrated on the island of Java. However, millions have moved to other islands throughout the archipelago. The Sundanese, Malay, and Madurese are the next largest groups in the country, while many ethnic groups, particularly in Kalimantan and Papua, have only hundreds of members.

On the course of Indonesian history, foreign origin ethnicities were spread throughout Indonesia. Some of these foreign ethnics include Chinese and Arabs (Wolff \& Poedjosoedarmo, 2002:3). Most Chinese are concentrated in pecinan (chinatowns) in Java, Sumatra and Kalimantan, with significant numbers in Jakarta, Medan, Semarang, Surabaya, Cirebon, Bangka island and Pontianak in West Kalimantan. As for Arabs, they have assimilated into local ethnicities such as Betawi, Malay, Javanese, and Sundanese (http://en.wikipedia.org/wiki/Ethnic_groups_in_Indonesia).

According to the 2000 census, the Chinese Indonesians make up a little less than $1 \%$ of the total Indonesian population. Some of these Chinese descendants speak various Chinese dialects, most notably Hokkien and Hakka (http://en.wikipedia.org/wiki/Ethnic_groups_ in_Indonesia). The Javanese and Chinese descendants (Peranakan) form two sub communities of the Javanese by virtue of their respective linguistic repertoires.

In a multicultural nation like Indonesia, there are so many stereotypes. Stereotypes are generalizations about a group of people where one attributes a defined set of characteristics to this group. These 
classifications can be positive or negative, such as when various nationalities are stereotyped as friendly or unfriendly (http://changingminds.org/explanations/theories/ stereotypes.htm). Some examples of Indonesian ethnic group stereotypes can be described below:

1. Chinese people in Indonesia are considered mean, stingy, and money oriented.

2. People from Padang (West Sumatra) cannot be trusted

3. Javanese are thought to be hypocrite because what they say is different from what they mean

4. Bugis (Sulawesi) people like to "back stab"

5. Minahasan are party lovers and wasteful

6. Ambonese always use physical strength instead of brain

7. People from Dayak (Borneo) are lazy

8. People from Batak (North Sumatra) are rude (http://www.anneahira.com/perang-antar-suku.htm)

However, as Davidson (1987) claims, an ethnic joke is neither necessarily the vehicle for prejudice, nor damaging in its effects. In terms of jokes which involve racial groups, the implied claim is that a racial joke -one with race as its subject- is not necessarily racist.

\section{METHOD}

This research is a qualitative one. Therefore, it results in descriptive data. This research described the data by explaining those data without involving any statistical procedures. Furthermore, the researchers employed three steps that include collecting, analyzing, and presenting the data (Sudaryanto, 1993:5-8). The data were collected from the texts in Sing Lucu rubric in the online version of Panjebar Semangat magazine (http://www.panjebarsemangat. co.id/) in January - August 2012. Then, these texts were analyzed by classifying the jokes based on their types. Next, the data analysis was presented and discussed. A loose translation of the jokes was also provided in the transcription to help understanding the data.

\section{FINDINGS AND DISCUSSION}

The jokes in Sing Lucu rubric in Panjebar Semangat magazine are classified into three types. They are positive, negative, and neutral jokes. Jokes that do not contain taboo elements (such as sexual matters) are considered as positive and neutral jokes, while those containing taboo and stereotypes of certain races are considered negative. Some jokes are not based on facts and therefore they do not always represent certain races 
stereotyped in such jokes. Although the jokes are written Javanese and are published in a Javanese magazine, the contents of these jokes demonstrate the multiculturalism of Indonesia.

\section{Negative Jokes}

Negative jokes are the ones that deal with ethnic stereotyping and sexual humors. The excerpts below demonstrate negative jokes found in Sing Lucu rubric in Panjebar Semangat magazine.

\section{Ethnic Stereotyping}

Excerpt 1 shows wordplay that uses sounds of language to create a humorous effect. A sound is the smallest unit in language. In humorous texts, what is expected to be assumed is deviated into another similar sound.

\section{Excerpt 1: Bahasa Cina}

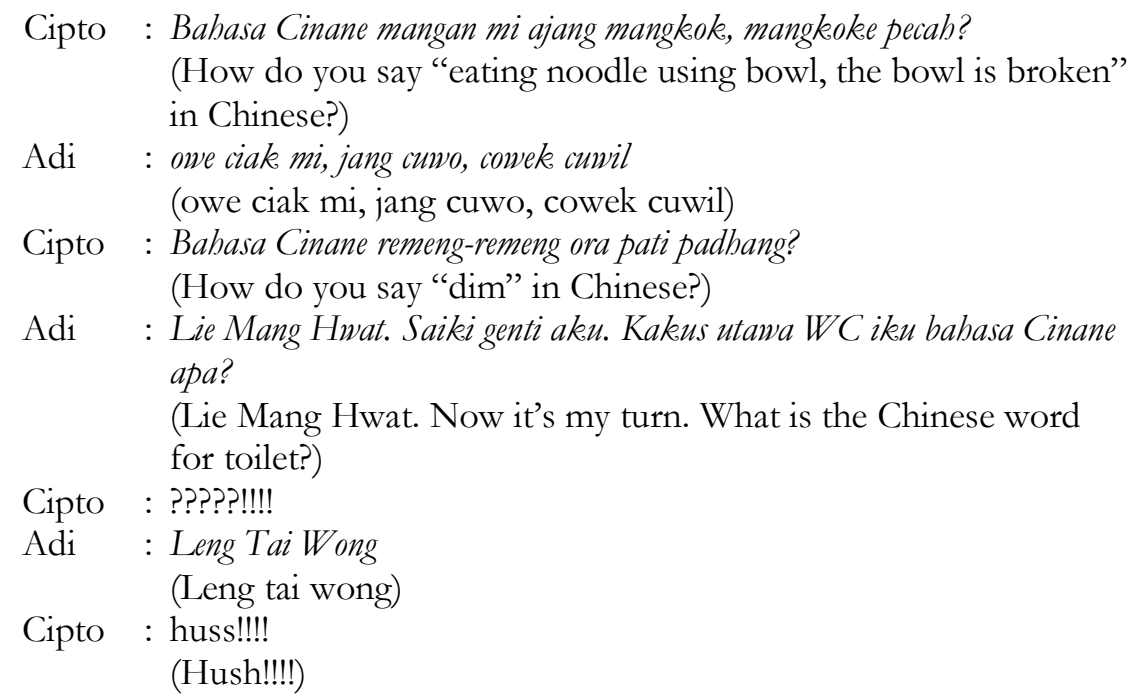

From the text above, Cipto and Adi give each other riddles involving Chinese language. In fact, this is a kind of joke that uses language play since they use Javanese words that sound similar to Chinese. The sentence "owe ciak mi, jang cuwo, cowek cuwil" is similar to Chinese in that it uses several Chinese (Hokkien) words such as owe (I), ciak (eat), mi (noodles), mixed with Javanese words cuwo, cowvek (bowl) and cuwil (broken). The speakers modify Javanese language so as to create a humorous effect that it sounds like Chinese language. The next sentence "Lie Mang Hwat" is also similar to Chinese. Lie Mang Hwat is actually a language play from 
"limang watt" (5 watts), meaning that that 5 watt lamp is not so bright. The other sentence used is "Leng Tai Wong". This is a modification of Javanese language, leng 'hole', tai 'excrement', wong 'person'. This also creates a humorous effect as it also sounds like a Chinese sentence.

The joke above is included into negative jokes because it uses Chinese words which create negative meaning. The word " $t a \imath$ " is considered negative and harsh in Javanese culture. The use of Chinese words to refer to something considered bad may also create negative effect as it can be a form of mockery to Chinese descendants in Indonesia.

Meanwhile, the use of Hokkien Chinese shows the existence of Hokkien or Chinese community in Java. Traced from the history of Chinese Indonesian (http://en.wikipedia.org/wiki/Chinese_Indonesians), Hokkien became the prevailing immigrant group until the middle of the $19^{\text {th }}$ century. These Hokkien descendants are the dominant group in some parts of Indonesia including Central and East Java, areas where Javanese is spoken. Therefore, Hokkien becomes one of major Chinese speech groups in Indonesia. In 1982 it was estimated that there were 700.000 speakers of the Min Nan language family, which includes Hokkien. It is not surprising then that there are jokes in Java or Javanese that involve the use of Javanese and Hokkien.

Another example of joke using Chinese sounding language can be seen in the following text:

\section{Excerpt 2: Cangkriman}

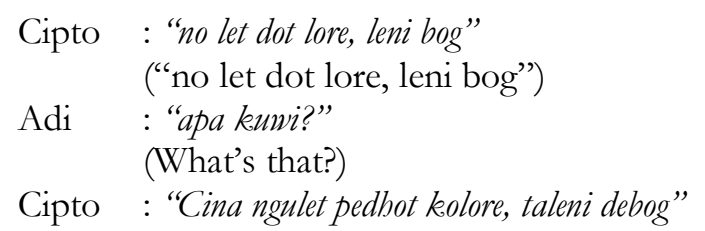

(A Chinese stretches his body and then his pants elastic is broken off, and he uses banana tree bark to tie his pants.)

Adi : "genti aku, yen kaya ngono wae pinter. Yu wot li, li njir cing, ngok pune kot yu."

(My turn, I'm good at such thing. Yu wot li, li njir cing, ngok pune kot yu.)

Cipto : Apa kuwi?

(What's that?)

Adi : "mbakyu mowot kali, kaline banjir cincing cincing, bengok-bengok pupune cokot yuyu."

(A woman passes a flooded river. She pulled her skirt up and she screams because her thigh is bitten by a crab). 
In the text above, the Javanese words "Cina ngulet pedhot kolor'e, taleni debog" are clipped so only parts of their syllable are left to create Chineselike words (no let dot lore, leni bog). The syllables which are clipped are the last ones (Cina ngulet pedhot kolore, taleni debog), and when they are pronounced they sound similar to Chinese language.

In Indonesia, a Chinese man is sometimes stereotyped as a person who likes wearing black boxer pants which have elastic instead of a zipper, white undershirt, and holding a fan. While the banana tree bark is usually used like a string to tie things by Javanese. The sentence "Cina ngulet pedhot kolor'e, taleni debog" infers another negative stereotype of Chinese in Indonesia, that they are often regarded as stingy people. The description about using banana tree bark (i.e., instead of getting a new zipper) demonstrates this kind of character.

\section{Sexual Humor}

The Eastern culture considers sex as taboo. Therefore, jokes containing taboo topics are delivered indirectly. In Panjebar Semangat magazine, there are humorous texts that have sexual content or association, although they eventually refer to non-sexual matters.

\section{Excerpt 3: Dawa sirah ing tengah}

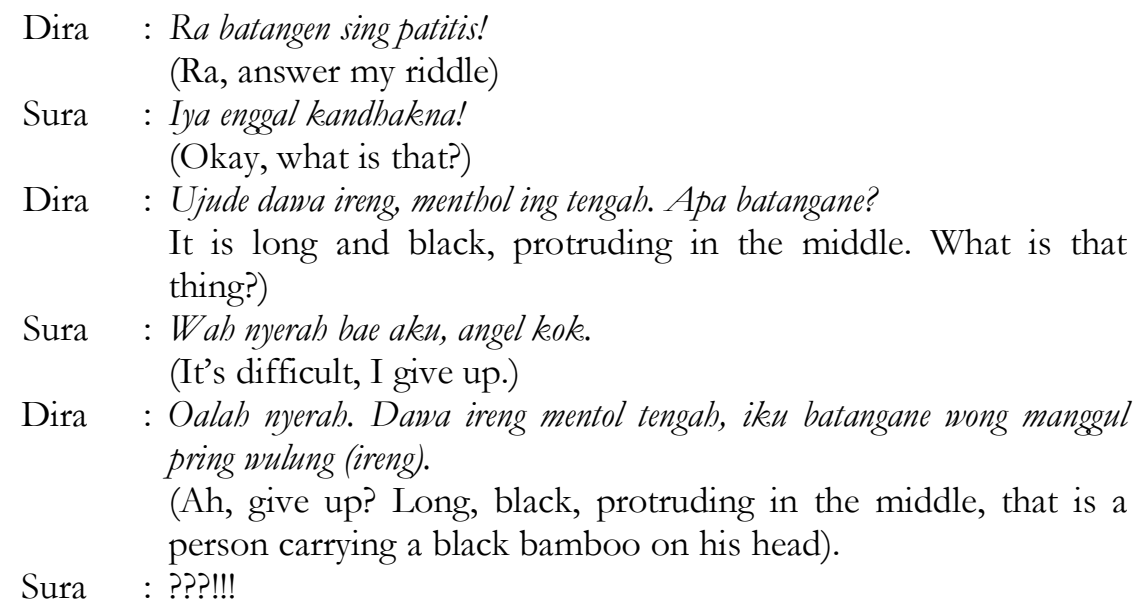

The excerpt above is an example of a negative joke which relates to sexual theme in the form of a riddle. The riddle is given by Dira by asking what is long, black, and protruding in the middle of something. When Javanese people hear this kind of question, at first they will assume or associate that the thing is related to a man's genital. Meanwhile, talking about sexual part is considered taboo especially in Javanese. The black 
bamboo is associated with a male's genital so as to create ambiguity which then gives humorous effect.

The excerpt below also deals with sexual joke which uses vowel sounds to trigger the humorous effect.

\section{Excerpt 4: Beda Vokal}

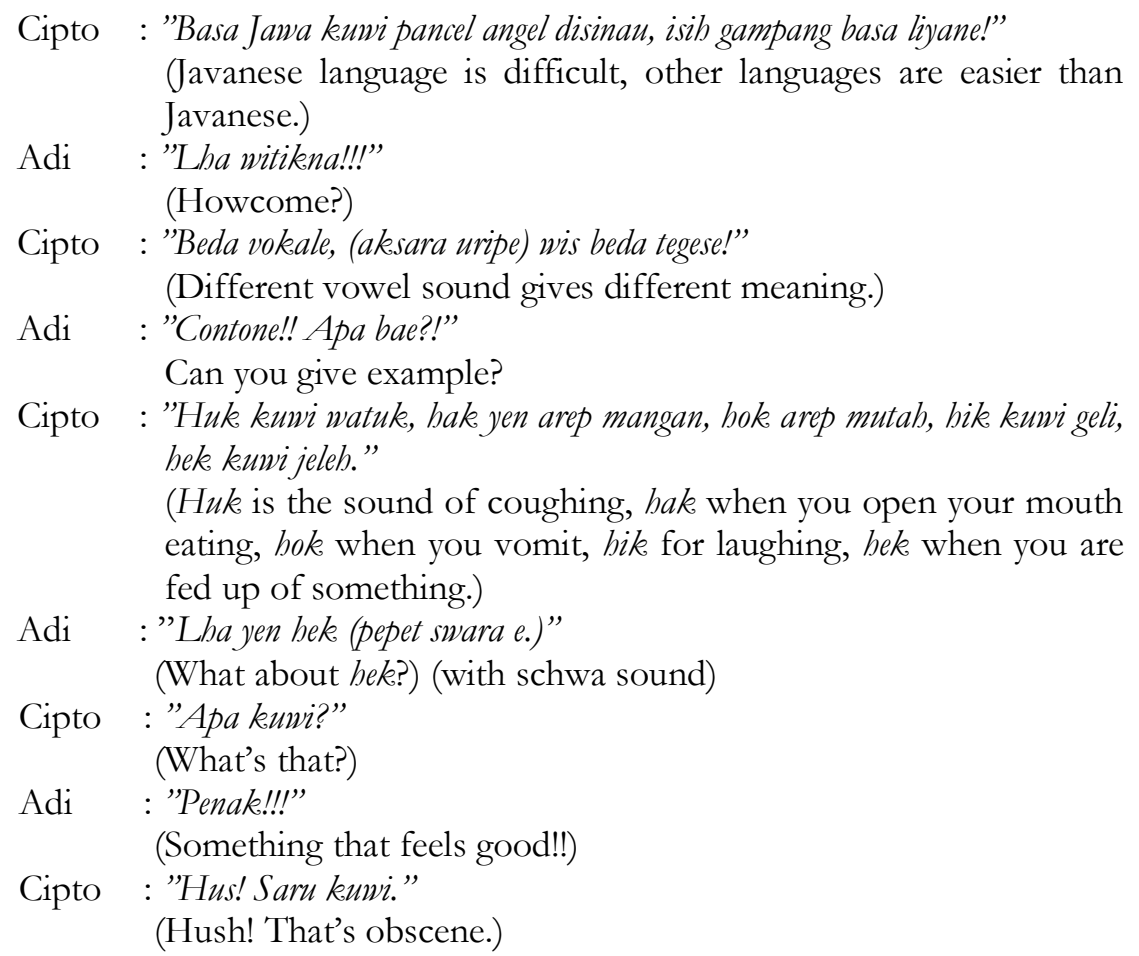

The joke uses language play in phonological form, especially in Javanese vowel sounds. To create the humorous effect, people usually associate certain sounds with certain situation or meaning. The excerpt above demonstrates that different vowel can create different meaning in Javanese. For example buk [hY?] is the sound of coughing. Then bak [ha?] is usually used when a person asks another person to open his/her mouth when feeding him/her, bok [hO?] when someone vomits, bik [hI?] for laughing, bek [he?] when one is fed up of something. The punch line in this

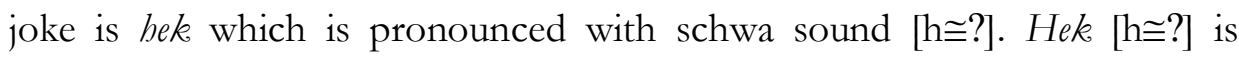
related with something that feels good. What "feels good" here has a sense of one's expression when he/she is having a sexual intercourse. Furthermore, it is supported by the response of that joke, which is "bus! Saru kuwi." (Hush! That's obscene.). When Javanese people say the word "saru", it usually deals with something vulgar, obscene, or inappropriate. 
Another joke that deals with sexual matter can be found in the following excerpt.

\section{Excerpt 5: Bedhekan}

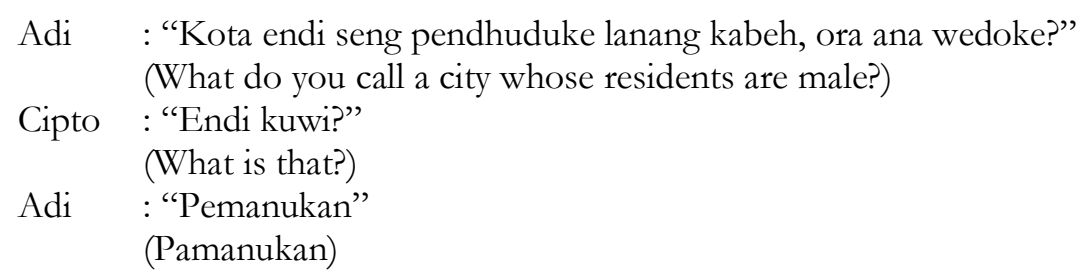

The joke in the excerpt above tells about a name of a city of Pamanukan, a city in Madura Island. The answer is a kind of wordplay of the word "manuk" which literally means bird in Javanese. In Java, manuk is used to refer to male's genitalia; therefore it can be implied from the joke that Pamanukan is a city with male residents only.

\section{Positive Jokes}

Positive jokes function to entertain the readers without having to relate the jokes with ethnic stereotype or racial prejudice or taboo topics. This type of joke usually contains positive aspects of Javanese or other cultures.

\section{Excerpt 6: Bedhekan 1}

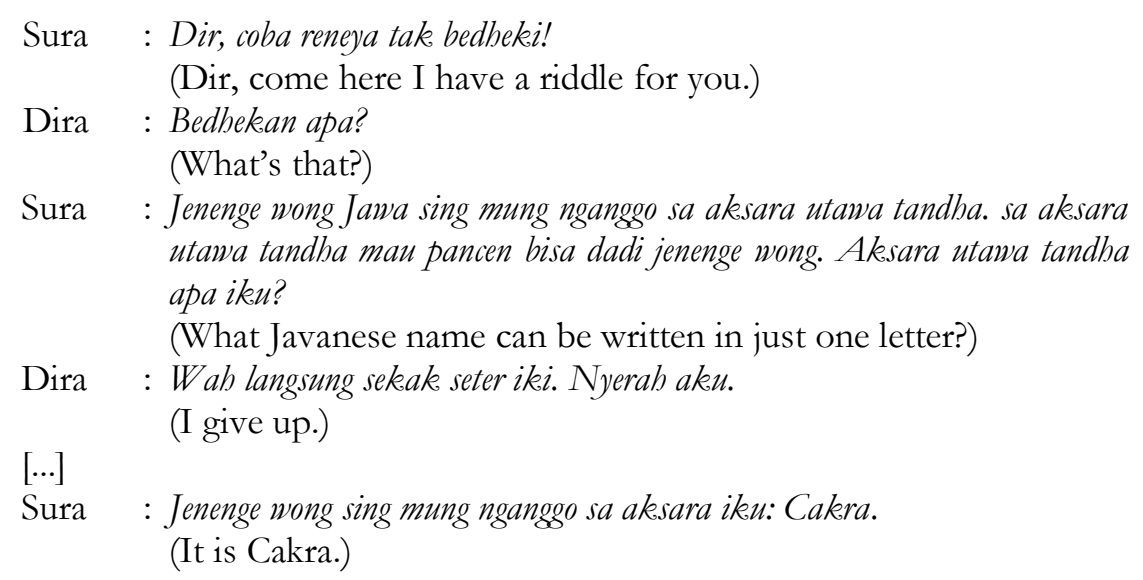

The excerpt above is about a riddle which relates to Javanese alphabet. It is about a Javanese name which can be written in just one letter. The answer is Cakra. Cakra ( $($ ) is a Javanese letter or symbol which represents a cluster of sounds containing / $\mathrm{r} /(\mathrm{CCV}$, or specifically $\mathrm{C}-\mathrm{ra}-$ 
$\mathrm{V}$; examples including cakra, putri, krama). Cakra is also a common Javanese name. This joke is considered positive because the joke writer can make the reader recall Javanese letter. Nowadays, many Javanese can not write or read Javanese alphabet as it is not used as the main alphabet in Central Java and East Java. Javanese writing is only taught in schools where Javanese is spoken but in practice there is no media using this alphabet. Javanese alphabet is usually found in old literature.

\section{Excerpt 7: Bedhekan 2}
Dira : Ra, yen pancen kowe pinter coba bedheken! Jenenge wong arab mung nganggo sa aksara. Dicoba ayo?
(Ra, if you think you are really smart, answer my riddle! What is the Arabic name that can be written in one letter?
Sura : Tinimbang kesunven nyerah aku.
(I give up.)
Dira : Yen pancen wis ora bisa, ora mung jeneng wong arab bae nanging kanggo wong jawa ya bisa, sing mung bisa ditulis ngangoo aksara arab mung siji. Yaiku I (alip) ya ta?
It is an Arabic name that can also be used for Javanese. It is alif. Right? Sura : ????

The excerpt above is included into positive joke. It is a riddle about an Arabic name which can be written just by a single letter. It is a positive joke because it tells the relation between Javanese and Arabic through a name. "Alif" ( $(-)$ is the first letter in Arabic, but it is spelled and pronounced as "Alip" in Javanese. The [f] sound is not native to Javanese and Indonesian, but occurs in borrowed words from Arabic (http://www.gimonca.com/sejarah/pronounce.html). Since Javanese lacks the sound $[\mathrm{f}]$, most Javanese people compensate the $[\mathrm{f}]$ sound by pronouncing it as $[\mathrm{p}]$. The riddle shows the positive aspect of Arabic culture assimilation in Java as many Javanese use Arabic names.

\section{Neutral Jokes}

Neutral jokes have the same function as positive jokes. These jokes are aimed at entertaining the readers without involving ethnic stereotypes or racial prejudice and sexual matters.

\section{Excerpt 8: Benda Angkasa}

Joni : Rud, benda-benda angkasa sing dibutubke dening ibu-ibu rumah tangga kuwi apa, ayo?

(Rud, what space object is needed by housewives?) 


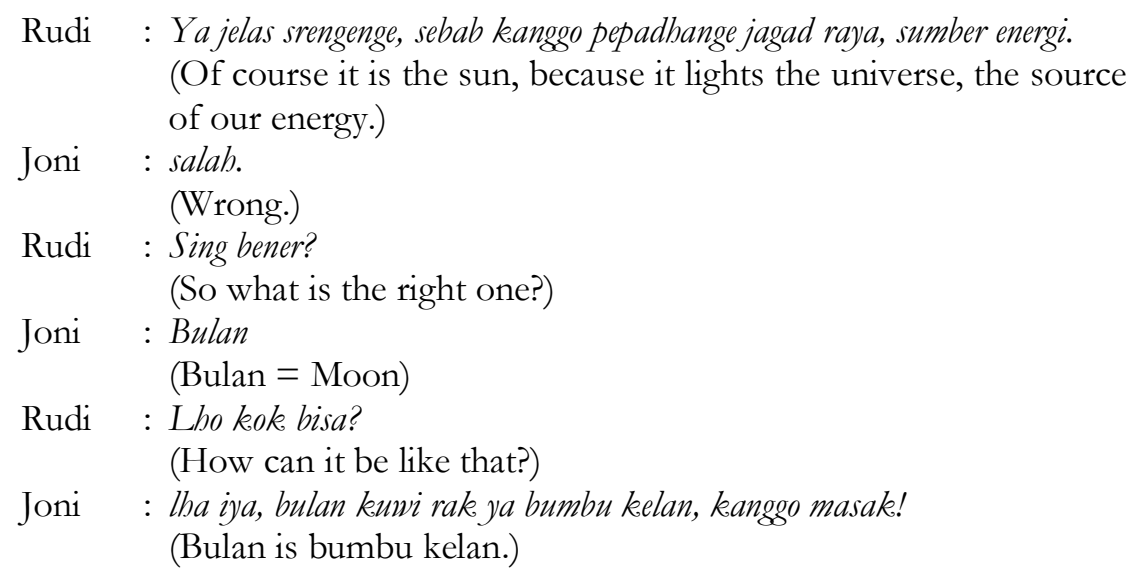

The excerpt above is the example of a neutral joke. It is a riddle about the name of a space object which relates to a housewife. The answer of the riddle is bulan (the moon), clipped from the words bumbu (spice) and kelan (a type of Javanese dish). It is included in neutral joke because the joke is not concerned with certain negative ethnic stereotype. The joke illustrates the diversity of Javanese dishes. Moreover, the word bulan is an Indonesian word. Hence, it shows the creativity in which Indonesian word can be clipped from Javanese words and shows the bilingualism in the country.

\section{CONCLUSION}

The humorous texts in Sing Lucu vary in type. There are three types of jokes, namely positive jokes, negative jokes, and neutral jokes. Although they all serve the same purpose, i.e. to entertain the readers, the positive and neutral jokes do not contain stereotyping of certain races and taboo or sexual humor, while negatives jokes do. Some jokes are not based on facts and therefore they do not always represent certain races stereotyped in such jokes. Furthermore, jokes with sexual or obscene contents are included in negative jokes because in Javanese culture, it is impolite or prohibited to talk about sexual topic in public.

\section{REFERENCES}

Alexander, Richard. 1997. Aspects of verbal humour in English. Tu“bingen: Gunter Narr Verlag.

Chiaro, Delia. 1992. The language of jokes: analysing verbal play. London: Routledge.

Crystal, David. 1998. Language Play. Chicago: The University of Chicago Press. 
Davidson, Chandler. 1987. Ethnic Jokes: An Introduction to Race and Nationality. Teaching Sociology, Vol. 15, No. 3 (Jul., 1987), pp. 296-302

Dienhart, John. 1999. A linguistic look at riddles. Journal of Pragmatics 31.95125.

Dynel, Marta.2009. Beyond Jokes: Types of Conversational Humor. Language and Linguistics Compass 3/5 (2009): 1284-1299.

Hermintoyo, M. 2011. Aspek Bunyi sebagai Sarana Kreativitas Humor. Jurnal Kajian Sastra Vol. 35, No. 1, pp. 14-27.

Lefcourt, H. M. (2001). Humor: The psychology of living buoyantly. New York: Kluwer Academic.

Mel'c uk, Igor. 1995. Phrasemes in language and phraseology in linguistics. Idioms: structural and psychological perspectives, ed. by Martin Everaert, Erik-Jan van der Linden, Andre' Schenk and Rob Schreuder, 167-232. Hillsdale, NJ: Lawrence Erlbaum Associates.

-1 1998. Collocations and lexical functions. Phraseology: theory, analysis, and applications, ed. by Anthony P. Cowie, 23-53. Oxford: Oxford University Press.

Norrick, Neal. 1993. Conversational joking: humor in everyday talk. Bloomington: Indiana University Press.

Raskin, Victor. 1985. Semantic Mechanisms of Humor. Dordrecht: D. Reidel Publishing Company.

Raskin,Victor. 1979. Semantic Mechanisms of Humor. Proceedings of the Fifth Annual Meeting of the Berkeley Linguistics Society. pp. 325-335

Ruch, W. 1996. Measurement approaches to the sense of humor: Introduction and overview. Humor, 9, 239-250.

Scheel, T and C. Gockel. 2017. Humor at Work in Teams, Leadership, Negotiations, Learning and Health. SpringerBriefs in Psychology. DOI 10.1007/978-3-319-65691-5_2.

Wijana, I Dewa Putu. 2003. Wacana Dagadu, Permainan Babasa, dan Ilmu Bahasa. Pidato Pengukuhan Jabatan Guru Besar pada Fakultas Ilmu. Budaya UGM. Yogyakarta: Fakultas Ilmu Budaya, Universitas Gadjah Mada.

Wolff, John U. \& Soepomo Poedjosoedarmo. 2002. Communicative Codes in Central Java. Ithaca: Southeast Asia Program Publications, Cornell University.

Websites:

http://en.wikipedia.org/wiki/Ethnic_groups_in_Indonesia

http://www.gimonca.com/sejarah/pronounce.html

http://changingminds.org/explanations/theories/stereotypes.htm

http://www.anneahira.com/perang-antar-suku.htm 